\title{
NATIVE AMERICAN LAND RIGHTS IN SOUTHERN ARIZONA 1
}

\section{Elliot McIntire}

One of the themes which ran through the Ninth International Conference of Historical Geographers in Perth and its Pre-Conference Symposium in Singapore was the rights to land ownership by peoples of the First Nations. Nancy Hudson-Rodd raised this question with regard to Indians in Canada and Aboriginals in Australia. A. J. Christopher examined the situation of Bantu peoples in South Africa, and Catherine Robinson presented a detailed look at the case of the people of the Torres Strait area. I would like to examine this question from the perspective of the situation in the United States, not only because it is inherently interesting, but because of the broader concerns it raised in the early part of this century with regard to land tenure in the Southwestern United States, which had echoes reverberating until well past the mid-century mark.

Differing concepts of land ownership have been at the heart of much of the conflict that accompanied the European expansion and settlement of the area that became the United States. Don Meinig, in Continental America 1800-1867, the second volume of The Shaping of America, his monumental historical geography of North America, develops this theme at length. The very different interpretations of treaties and agreements by the parties involved were fundamental to many of the conflicts that arose during this process. Meinig points out in his discussion of treaty boundaries:

It was of course clear ... that such boundaries were not immutable. They were not intended to be; they were understood by those who imposed them to be geopolitical devices to effect orderly change, a means, so it was always argued, to allow the reasonable expansion of the one people without the destruction of the other. ${ }^{2}$

In contrast, the native inhabitants of these regions viewed such agreements as recognition of their sovereignty and sacred rights to the land.

Earlier, William Cronon had pointed out that different concepts of land tenure were responsible for the differing approaches taken by the Indians of New England and the European settlers who replaced them. ${ }^{3}$

Elliot McIntire is currently Professor of Geography at California State University. His doctoral dissertation dealt with settlement and land use patterns on the Hopi Indian Reservation in northern Arizona and much of his research has focussed on historic change in the settlement and land use of native American lands in the Southwest.

1 An earlier version of this paper was presented at the Ninth International Conference of Historical Geographers, in Perth, Western Australia, July 7, 1995. Research for this study was supported in part by a grant from the California State University, Northridge Foundation. Much of the material used is found in manuscript form in the records of the U.S. Indian Claims Commission on the Papago land claim, primarily in the materials of Office (later Bureau) of Indian Affairs investigator William Bowie, who looked into the HunterMartin claims in 1915-18 (Bowie 1919, Cook 1973).

2 Meinig 1993:79.

3 Cronon 1983. 
F. P. Prucha has stated this position in a different way.

Underlying United States policy was an overriding concern for the advance of White settlement, for it was an axiom that the expansion of White civilization should not be obstructed or prevented by hunter or agricultural societies, spread thinly over the land, and not fully using the resources according to White standards. 4

In the Southwest these issues were complicated by the presence of yet a third view of land tenure, that of the Spanish and their successors, the Mexican government. It is within this context that the struggle for control of the traditional lands of the Tohono O'odham must be assessed.

The Tohono O'odham (until recently generally known as the Papago) have a well defined sense of their traditional lands which they have occupied for at least the last several centuries: roughly everything in southern Arizona south of the Gila River and west from the Santa Cruz River valley, extending well into what is now Sonora, Mexico. Within this area family groups moved between summer and winter village sites and farm lands around permanent water sources, and shared hunting grounds and gathering areas with other such groups. Although individual saguaro cacti (the fruit of which provided one of the group's staples) might be individually owned, other resources were shared in common.

This, of course, conflicted with the American view of resource ownership, which was one of individual tenure, and that areas that were not obviously utilized, such as fields or home sites, were unowned. In the context of the American legal system, such lands were viewed as part of the public domain.

Under Spanish, and later Mexican law, a distinction was made among the aboriginal inhabitants of their territories. 'Wild' Indians were not viewed as citizens, and had no property rights. On the other hand, 'civilized' Indians who were settled in permanent villages and practiced agriculture were recognized as citizens, with all property rights to the lands they utilized, just as any other citizen. Although the law did not require it, this status was often confirmed by charter or other 'official' recognition by the national government. Most of the New Mexican pueblos, for example, had received such recognition, but, although the Spanish and Mexican governments dealt with the Tohono O'odham as settled peoples, no such documentation was ever developed. ${ }^{5}$ And, since the Tohono O'odham did not live year around in large, permanent villages like the New Mexican pueblos, American settlers did not view them as having the same status.

When much of the northern Mexican territory was added to the United States under the treaty of Guadalupe Hidalgo in 1848, and the area south of the Gila River were added by the Gadsden Purchase in 1853, the rights of all Mexican citizens were explicitly protected and confirmed. The story of how much of this land in California, New Mexico and Texas was transferred to Anglo owners in the course of the legal challenges that followed annexation is a complex one, and has been dealt with elsewhere. The status of Tohono O'odham lands was at best, ambiguous under these provisions. It is the legal vacuum created by this situation that I wish to examine.

The Tohono O'odham had been a peaceful people, early converts to Catholicism, and frequent allies of the Spanish and Mexican governments in fighting off the increasingly frequent raids of the Apache into the settled areas of the Pimaria Alta (southem Arizona and

4 Prucha 1988:40.

5 Those Tohono O'odham who remained on the Mexican side of the international border were viewed as citizens able to sell their land. Within a short period, most of their lands had been acquired by non-Indians, and most of the dispossessed Tohono O'odham gradually moved north, joining their relatives in the United States. 
northern Sonora). During the early nineteenth century the Tohono O'odham had largely withdrawn from their settlements east of the Santa Cruz River, as had many of the Spanish/Mexican ranchers in the area, under the pressure of Apache raiding. Just as they had previously allied themselves with the Spanish and Mexican settlers, the Tohono O'odham joined with the newly arrived Americans in resisting the incursions of the Apache.

Since the American settlers were concentrated in the river valleys already abandoned by the Tohono O'odham, and the desert lands to the west were generally unattractive to the Americans, there was little cause for friction between the two groups. As a result, no Indian Agent was appointed for them until well into the American period, and, with minor exceptions, no reservation was set aside for their use. During this period (1853-1916) all the lands occupied by the Tohono O'odham were viewed by American officials as part of the public domain, and since the tribe had no occasion to assert their rights to the land, nor any awareness that they needed to do so, this view went unchallenged. ${ }^{6}$

The only real potential for conflict was in the fertile agricultural lands near the San Xavier del Bac mission (where a small reservation was created in 1874), and those water sources located near newly discovered mineral deposits in the desert to the west. ${ }^{7}$ In fact, it was one of these water sources that precipitated the chain of events examined below.

In the early 1870s a Tucson merchant named Solomon Warner filed a claim to the Santo Tomas mine, which included one of the few permanent water sources in the Santa Rosa Valley, some 50 kilometers west of Tucson. This was of concern to the Catholic Indian Mission Society, headquartered in Washington, D.C., since, if deprived of access to water, the Tohono O'odham settlement would be unable to survive. Although it does not appear that there was immediate development of the mine, the Mission Society filed a protest with the General Land Office in 1874, followed by a second protest in 1880 and in late 1880 Colonel Robert F. Hunter arrived in Tucson on behalf of the Mission Society, to 'arrange for the protection of the Papago [Tohono O'odham] Indians ... in the rights to lands.'

Colonel Hunter is one of many interesting characters who helped shape western history. Although described in later accounts as an Arizona pioneer, rancher, trader, fearless defender of Indian rights, missionary to the Papago, and Civil War hero, he was none of these. A West Point graduate, he rose no higher in rank than Captain, and was cashiered for drunkenness on duty in Washington, D.C. early in the Civil War. Through family connections he eventually obtained a position with the Catholic Indian Mission Society, even though he was not Catholic. In 1880 he traveled to Tucson, where he stayed for several weeks, apparently his only visit to Arizona. On two occasions, groups of Tohono O'odham were brought together at the home of Bishop Salpointe in Tucson, where a number of deeds were executed. According to a witness, the deeds were not translated, or even read in English, or in any way explained to the Indians, who were merely told to sign.

6 By Act of Congress on October 1, 1886 (Stat. L., XI, 374) the U.S. asserted its ownership of all areas west of the Santa Cruz River and south of the Gila River occupied by the Papago, Pima, and Maricopa Indians. Charles Royce, in his massive study of Indian land cessions, states "No treaty of purchase was ever made with these tribes, who have a common origin. The U.S. took possession of their country, the boundaries of which are shown on Arizona map No. 1. Reservations were, however, assigned them, upon which they were concentrated...." (Royce 1899). Royce erred in this assessment. Only those Tohono O'odham who already lived on the tracts set aside occupied them. Most remained outside the reservation system.

McIntire 1977. 


\section{NATTVE AMERICAN LAND RIGHTS, ARIZONA}

These deeds covered many of the areas occupied by the Tohono O'odham, and conveyed an undivided half interest in these lands to Hunter, presumably so that he could act on their behalf in any legal actions taken (Figure 1). Such documents acquire legal standing only when recorded at the local land office, but curiously, Hunter did not record these deeds. Instead, he retumed to Washington, where, for the next two years he made repeated unsuccessful efforts to get the United States Surveyor General for Arizona to investigate the legal basis of Tohono O'odham land title under Spanish and Mexican law.

Hunter seems to have made some sporadic attempts to follow up on this issue over the next decade or so, but the story really jumps ahead to 1911. The eighty year old Hunter, visiting his children in Los Angeles, sold a three-fourths share of his undivided half interest in these lands to one Robert M. Martin, a Los Angeles real estate developer and stock manipulator, for $\$ 6000$ to be paid in installments, with an option on the remaining onefourth for $\$ 250,000$ when the land was segregated. Hunter soon died, leaving his estate (the deeds) to his eight children.

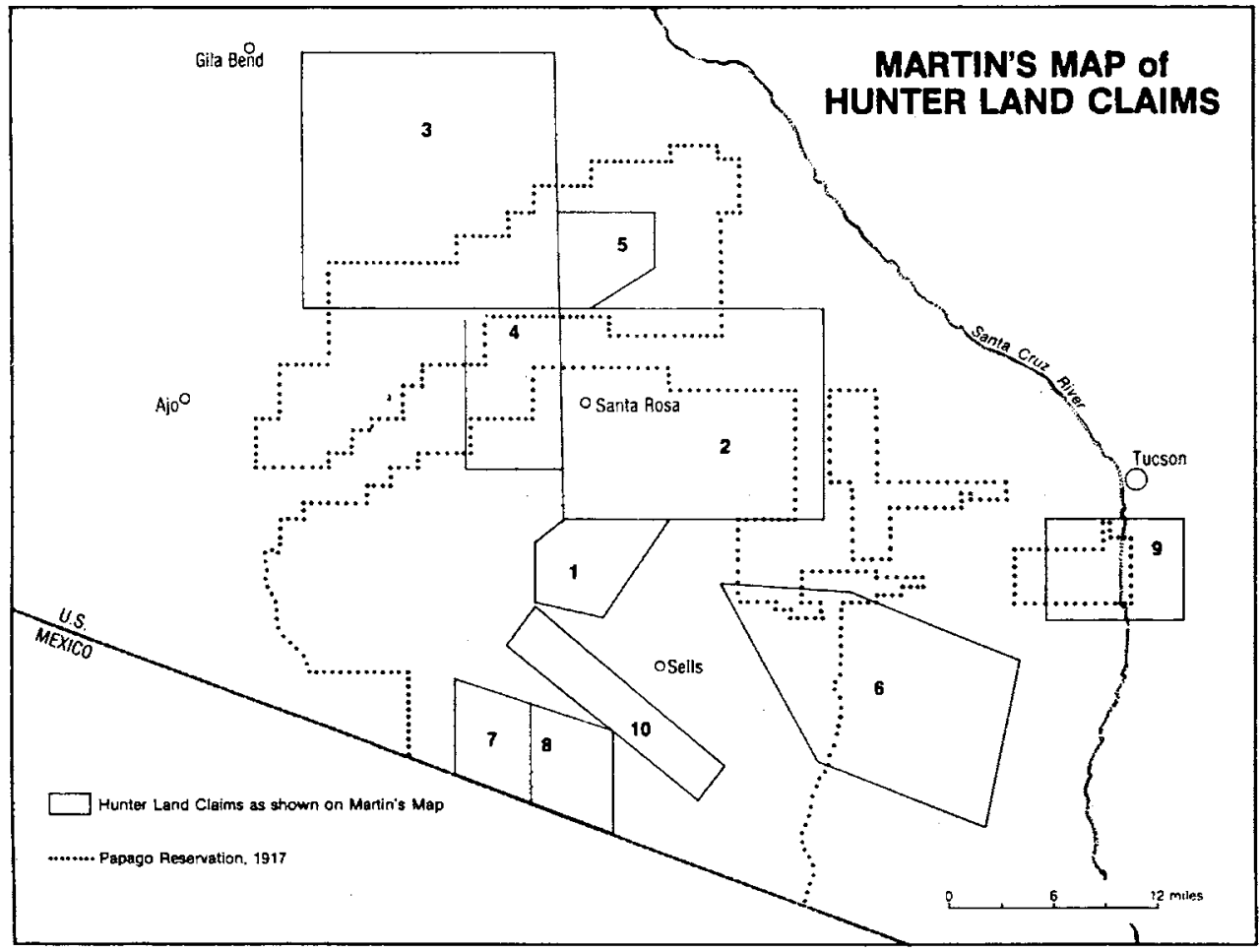

Figure 1. Location of Hunter's Deeds In Relation to the Papago Reservation. 
According to the heirs, this sale was with the understanding that Martin would bear the cost of having the land surveyed and segregated from the public domain, as well as any legal expenses involved, with 'all proceedings to be instituted in the name of the Indian inhabitants of the respective villages named in the deeds.'

The proposition was clearly very attractive to the Hunter heirs: some immediate return, and the prospect of a sizable income in the future, with no risk to them, all for otherwise worthless deeds their father had been holding onto for thirty years. For Martin, it gave him potential access to a huge area of southern Arizona for a very modest investment.

There seems to have been some differences among the heirs, but two, Executrix Virginia Hunter and son-in-law C. B. Guittard became seriously involved, and Guittard worked closely with Martin for several years. In fact, it was Guittard who recorded ten of these deeds at the Pima county courthouse in Tucson in June, 1914. A year later, a suit was filed in Washington, D.C. on behalf of 'the Pueblo of Santa Rosa' (one of the larger Tohono O'odham settlements), seeking to enjoin the Department of the Interior and the General Land Office from 'illegal encroachment upon its land' by treating it as part of the public domain, permitting mining and homesteading claims to be filed on it. As it turns out, the suit was filed on behalf of Martin, without the consent, or even the knowledge of, the inhabitants of Santa Rosa village.

On one level this suit could be viewed as an effort to assert the rights of the Tohono O'odham to ownership of their traditional lands. If the suit was successful it would establish that the tribe held title under Spanish and Mexican law (and therefore under U.S. law). If the courts also held that the Hunter deeds were not obtained fraudulently, Martin and the Hunter heirs would have title to half of the land around virtually all of the Tohono O'odham settlements. Presumably title to the rest of the lands would be assigned to the tribe.

However, it is difficult not to assign sinister motives to Martin and the Hunter heirs, for in retrospect it seems clear that the recording of the deeds and the filing of the lawsuit were merely devices to further one of the more creative land schemes in southwestern history. No effort was made to contact the Tohono O'odham regarding the suit, and the tribe did not even know that it had been filed. If the legality of title to the land could be obscured by legal maneuvering for several years Martin could proceed with plans to profit from the confusion. And, in fact, Martin had begun selling shares in his project even before the deeds were recorded.

Martin, or more probably, Guittard, provided a map indicating the lands covered by the deeds recorded in 1914. Martin had divided these lands, totaling approximately two million acres, into one thousand 'units,' with boundaries of these units unspecified. Five hundred of these were to be allocated to the Tohono O'odham as their share, while the remainder were available for sale as soon as the land could be segregated from the public domain, which of course, was dependent on a favorable outcome of the law suit. In the meantime, Martin, whose share was 375 units, with an option on the remaining 125, had already begun selling the first hundred units at $\$ 1,000$ each. A 1914 investigation by postal inspectors, suspecting mail fraud, showed that about ninety of these units had already sold. Since only units, not land, were offered for sale, the post office ruled that no fraud had occurred.

The greed exhibited by this operation is staggering. For an initial investment of $\$ 6,000$ (probably much less, since this was to be paid in installments) Martin already had a return of some $\$ 90,000$. Those who had purchased units would, if title to the land was confirmed, find themselves owners of some two thousand acres, somewhere in southern Arizona, for an investment of $\$ 0.50$ per acre. 


\section{NATTVE AMERICAN LAND RIGHTS, ARIZONA}

But the efforts to profit from these deeds did not stop with the 'unit' scheme. A number of organizations seem to have been set up to exploit these lands. The Bureau of Indian Affairs investigation turned up the American-Mexican Land \& Colonization Company, a wholly owned corporation of Martin's, which was inactive. A second scheme was the Santa Rosa Valley Colored Settlement project. There is no clear evidence of Martin's involvement with this scheme, but its similarity to the previously mentioned company makes one suspicious. In about 1916 the Progressive Education Association, active in the black community of Los Angeles, began to promote establishment of an African American community in southem Arizona. Its publicity noted that it had negotiated for ' 107,000 acres of the best farming land in the west' (see Appendices A and B). If we assume these were purchased from Martin, it would represent an investment of over $\$ 53,000$. This land was being offered in forty, eighty, or one hundred acres parcels, at $\$ 5.50$ per acre. Sale of all 107,000 acres would have come to nearly $\$ 600,000$.

Much of the literature for this project was freely adapted from a report for Martin written by Guittard, and a few extracts will give a sense of its content. The plains are green the year round, an ideal climate and a healthy country. Plenty of rain for two crops a year ...' The land will produce cotton and corn, 50 to 75 bushels per acre ... lemons and oranges, grapes and all kinds of nuts, and any fruit that grows in any semi-tropical climate.' The land is 'level valley land ... purely silt soil, absolutely free from alkali or clay,' and it notes that the Indians of the area grow their crops without irrigation, the rain being sufficient for two crops a year.

In contrast to these glowing accounts, the area is extremely arid, with rocky and sandy desert soils. The crops mentioned above can be grown only in the alluvial river valleys north and east of the Tohono O'odham country, and only with massive irrigation schemes. The agriculture practiced by the native peoples employed a very sophisticated locational scheme, which took advantage of the spread of runoff from torrential summer thunder storms where it spreads out at the mouths of mountain canyons, but sites for such fields are extremely restricted. 8

A recent observer of the area has characterized the precipitation in the following way:

A Sonoran Desert village may receive five inches of rain one year and fifteen the next. A single storm may dump an inch and a half in the matter of an hour on one field and entirely skip another a few miles away. Dry spells lasting four months may be broken by a single torrential cloudburst, then resume again for several more months. 9

Although there are no records of exactly how much land was sold under the colony scheme, the Bureau of Indian Affairs estimated that Martin had taken in over $\$ 1,000,000$. In the meantime, Guittard recorded additional deeds, which claimed an even larger portion of southern Arizona. As these legal questions worked their way through the courts, the government found itself in a curious position.

During most of the early history of the United States government policy toward native Americans was shaped by the assumption that they would soon disappear, and for most of this period, such a position was clearly justifiable. The population of nearly every group declined sharply, and several groups disappeared entirely, or their few remnants were absorbed by other tribes, while a handful assimilated into the dominant white culture. However, beginning with the 1880 census, it became increasingly clear that, far from disappearing, many tribes were rapidly increasing in population. Recognition of this fact

8

9 Nabhan 1987 
forced a reappraisal of official policy, and while many of the previous policies remained in place, there was a growing awareness that long term accommodation to a growing population would be necessary.

The establishment of many new reservations (nearly all in the far west) and an expansion of efforts to speed assimilation were elements in this new approach. A shift to government, rather than mission schools, and the allotment of Indian lands to individuals rather than to the tribe were part of this effort. The Tohono O'odham, however, never having opposed the United States, had generally been neglected by the government.

Late in the nineteenth century a few small reservations for the tribe had been established, primarily along the eastern and northern margins of their traditional lands, where irrigable river bottom lands were also attractive to white settlers. But as late as 1916 these reservations totaled only 148,000 acres, a minute fraction of the more than five or six million acres utilized by the tribe.

If Martin's suit prevailed, the Tohono O'odham would have title to a large portion of southern Arizona, including the obligation to pay property taxes, and the right to sell it. Given the history of other groups in the area, it is likely that within a very few years the tribe would have found itself essentially landless and impoverished. To prevent this by setting aside a reservation, the government had to maintain that the tribe did not hold title under Mexican law, and that the land was all part of the public domain. In January of 1916 President Wilson set aside, by Executive Order, a reservation of some 3,100,000 acres. Interagency correspondence makes it clear that creating of the reservation was largely an effort to preempt land sales by Martin and his associates. Although there were subsequent deletions and additions to this area, the tribe's current reservation is substantially the same as that set aside by Wilson (Figure 2).

However, in order to provide this reservation, it was necessary for the government to prove that the Tohono O'odham had no claim to the land. If the tribe had a legitimate claim under Spanish and Mexican law, then the Hunter-Martin deeds might well be found to be valid, and the sale of much of the tribe's traditional lands would proceed. If, on the other hand, they had no legal claim to it, then the whole area was within the public domain, and the government could set it aside as a reservation for the tribe.

Although the suit was eventually dismissed by the United States Supreme Court in 1927, it was only on the technical grounds that the ostensible plaintiffs, the people of Santa Rosa village, had not authorized the suit. This ruling clearly left the basis for Martin's claim to the land unresolved. But by the time of the ruling Martin's 'unit' sales had long since stopped, and no more was heard from Martin or the Hunter heirs. The government proceeded to act as if the Supreme Court's ruling had validated its position, although it was, in fact, still an open question. As a result, property owners throughout southern Arizona, and indeed, much of the southwest, remained apprehensive about the legality of the title to their land. It is likely that this case (and others) was a significant contributing factor in the establishment some twenty years later of the United States Indian Claims Commission to 'deal finally with the long-standing claims of Native Americans against the Federal Government. 10

10 The government of the United States cannot be sued without Congressional approval, but the Indian Claims Commission Act of 1946 established a tribunal to hear all suits from recognized tribes which filed claims within five years of enactment, and nearly five hundred claims were filed. By filing a claim, tribes explicitly waived any future claim against the U.S. The commission held hearings with both sides presenting expert witnesses on the exclusive utilization of lands by the tribe at the time the land was taken from them. When 


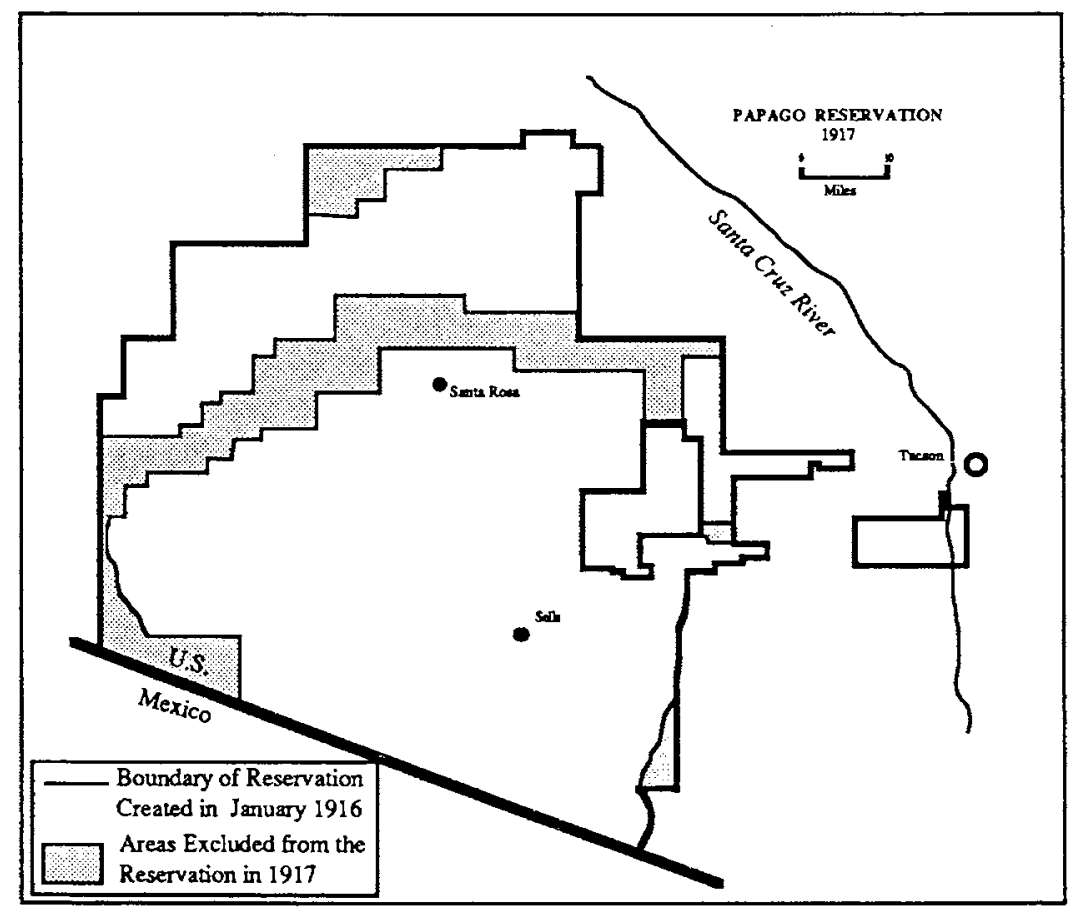

\section{Figure 2. The Papago Reservation in 1916 with later modification}

When the Tohono O'odham (Papago) claim was finally settled in 1976 the ruling held that the tribe had held aboriginal title to virtually all of the area south of the Gila River and west of the Santa Cruz River, an area virtually identical to the Hunter claims, and was entitled to compensation of $\$ 26,000,000$ for lands taken, the loss of subsurface rights, and trespass prior to the taking of the lands. It is worth noting, however, that the title was based on aboriginal possession, not title under Spanish or Mexican law. In effect, the Commission ruled that Hunter's basic argument was correct: the tribe did have title, and that the government should not have treated their lands as part of the public domain. ${ }^{11}$ All

areas were used by more than one tribe, neither received compensation for it. The area of reservations was also excluded (since the tribe retained this land), and compensation was computed at the value of the land at the time of taking. This usually was less than a dollar an acre. The Commission, originally scheduled for a ten year existence, continued to function until 1978, when its 68 remaining cases were transferred to the Federal Court of Claims. (Imre Sutton 1985).

11 While this, and other rulings by the Commission, acknowledged that the taking of some lands was illegal, the settlements also ratified the legality of subsequent land titles to these 


\section{ABORIGINAL HISTORY 1995 19:2}

land outside the reservation was confirmed as part of the public domain, and most of it remains in that status. Nearly all is within Organ Pipe Cactus National Monument, the Cabeza Prieta National Wildlife Refuge, or the Luke Air Force Bombing and Gunnery Range. The tribe has used much of the compensation for programs such as provision of water and electricity to remote settlements, stock improvement, and job training. Its most important result, however, was to give the tribe a degree of independence from funding controlled by the Bureau of Indian Affairs bureaucracy.

\section{LIST OF REFERENCES}

Bowie, William. 'Report of investigation connected with Equity Case No. 33201, the Pueblo of Santa Rosa vs. the Secretary of the Interior and the Commissioner of the General Land Office, Supreme Court, District of Columbia, test case involving validity of Indian Reservation lands in Southern Arizona', National Archives, Washington, D.C. Record Group 75, Entry 570. 1919.

Bryan, Kirk. 'Flood Water Farming', Geographical Review, 19, 1929:338-344.

Cook, Charles A. 'The Hunter Claim: A Colossal Land Scheme in the Papagueria', Arizona and the West, 13, 1973: 213-244.

Cronon, William. Changes in the Land: Indians, Colonists, and the Ecology of New England., Hill and Wang, New York.1983.

McIntire, Elliot. 'The Growth of the Papago Reservation', Historical Geography Newsletter, 7, 1977:66-67.

Meinig, Donald w. The Shaping of America: A Geographical Perspective on 500 Years of History. Vol. 2. Continental America, 1800-1867, Yale University Press, New Haven, Connecticut. 1993.

Nabhan, Gary Paul. The Desert Smells Like Rain. North Point Press. 1987.

Prucha, Francis Paul. 'United States Indian Policies, 1815-1860'. In Wilcomb Washburn (ed.). History of Indian-White Relations. (Handbook of North American Indians, William Sturtevant, general editor, vol. 4) pp40-50, Smithsonian Institution, Washington, D.C. 1988 .

Royce, Charles. Indian Land Cessions in the United States. Eighteenth Annual Report of the Bureau of American Ethnology to the Secretary of the Smithsonian Institution, 1896-97. Part 2. Smithsonian Institution, Washington, D.C.1899.

Sutton, Imre (ed.). Irredeemable America: The Indians' Estate and Land Claims., University of New Mexico Press, Alburquerque, N.M.1985.

areas. Thus, current land owners did not face the possibility of having their lands turned over to the tribe. The only significant exception came with the Maine Indian Claims Settlement Act of 1980 (P.L. 96-420), which authorized the Passamaquoddy and Penobscot Indians to reacquire some 300,000 of the 12 million acres taken from them in unratified transactions. Aboriginal title to much of Alaska was recognized under the Alaska Native Claims Settlement Act of 1971 (85 Stat. 688). 


\section{Appendix A}

Lands]

[Text of promotional brochure sent to prospective purchasers of Hunter-Martin

\section{SANTA ROSA VALLEY \\ Colored Settlement}

\section{YOUR}

\section{QUESTIONS}

ANSWERED

\section{WHERE IS THE LAND?}

In the wonderful Santa Rosa Valley of Pima and Pinal counties, in Southern Arizona.

\section{WHAT IS THE CHARACTER OF THE LAND?}

The land is level valley land, covered with a growth of native grasses, sage brush and grease wood. It is a purely silt soil, absolutely free from alkali or adobe, and several hundred feet deep.

\section{WHAT IS THE CLIMATE?}

It is comparable to that of Southern California. There are no great extremes of heat or cold. A light frost has been known only twice in twenty years, and there are no fogs.

\section{IS THIS A NEW AND UNKNOWN COUNTRY?}

No, it has been inhabited and these lands have been farmed for several hundred years. There is evidence of there having been a high state of civilization in this country when Columbus discovered America.

\section{WHO ARE THE INHABITANTS?}

We call them the Papago Indians, but they are citizens of the United States, and have the right to buy and sell property the same as other citizens. They are farmers and stock-raisers.

\section{WHAT AGRICULTURAL PRODUCTS DO THEY RAISE?}

In the winter months they sow their wheat and barley, which is harvested in May and June; in July they plant corn, beans, peas, melons, pumpkins, sorghum, etc. and harvest these crops in September and October.

\section{DO THEY IRRIGATE?}

No, they never irrigate; the rainfall has always been sufficient to grow two full crops a year without irrigation. If one should wish to irrigate an unlimited supply of water can be developed by pumping from wells.

\section{WHAT IS THE RAINFALL?}

There are two rainy seasons, the primary maximum occurring during the months of July, August and September, and a secondary maximum during the 
colder months of the year. Practically no rainfall occurs during the months of April, May, June, and October, November, and December. The average rainfall is from 16 to 30 inches per year.

\section{WHAT IS THE WATER SUPPLY?}

The land is all water bearing, wells of from 20 to 80 feet give all the water needed for domestic purposes, and deeper wells give an inexhaustible and unlimited supply for irrigation purposes if necessary.

\section{ARE THERE ANY HIGH WINDS OR CYCLONES?}

No, the U.S. Weather Bureau reports that the average wind velocities are comparatively light, ranging from above 4 miles to slightly above 7 miles per hour.

\section{WHAT WILL THE SOIL RAISE?}

Anything that can be raised in a semi-tropical country. In fact, these lands are susceptible of the highest cultivation of any lands in the world, in this latitude.

\section{WHAT ARE THE RAILROAD FACILITIES?}

The lands are about 20 miles due south of Casa Grande, a station on the main line of the Southern Pacific R. R. and a new Rail Road is projected through these lands.

\section{WHAT IS THE TITLE TO THESE LANDS?}

These lands are old Spanish grants and are guaranteed by treaty and the U.S. Government.

\section{DO I GET A GOOD TITLE TO THE LAND?}

Yes, the title is guaranteed.

\section{HOW IS THE LAND TO BE DIVIDED?}

In regular sections according to $U$. S. custom.

\section{IF I BUY, WHEN CAN I MOVE TO THE LAND?}

Just as soon as it is segregated, from public domain. The territory is still unsurveyed and our deeds are by meets and bounds.

\section{WHEN WILL THE SEGREGATION AND SURVEY BE MADE?}

Just as soon as we can get the Government to order it. We hope to have it done in less than a year.

\section{HOW WILL IT BE DIVIDED?}

In 80 acre tracts or less.

19. HOW WILL I KNOW WHERE MY LAND IS LOCATED?

When the land is surveyed you have the privilege of picking it out yourself. 


\section{NATIVE AMERICAN LAND RIGHTS, ARIZONA}

20. WHAT IS IT REASONABLE TO SUPPOSE THE LAND WILL RAISE?

Anything that any other land will raise, and a great many things that other farms will not: corn, sorghum, wheat, barley, alfalfa, oats, cotton, kaffir corm, milo maiz, potatoes, melons, and all kinds of vegetables, also dates, figs, olives, oranges, lemons and walnuts.

\section{IS IT A GOOD STOCK COUNTRY?}

Yes, we believe it unexcelled for hog, horse and cattle raising.

22. WHAT IS YOUR OPINION OF THE FUTURE VALUE OF THIS LAND?

It is reasonable to suppose that within five years from the time we get possession of our land it will be worth $\$ 150$ per acre.

23. ON WHAT DO YOU BASE YOUR ESTIMATIONS?

We know that land that will raise 40 bushels of wheat to the acre is worth $\$ 150.00$ per acre, in any land. And land that will produce 80 bushels of corn to the acre is worth $\$ 150.00$. This land is known to produce 60 bushels of wheat and 80 bushels of corn to the acre on the same land in the same year. We will demonstrate it in less than that time.

H. H. Williams and W. H. Rozier, 966 Hemlock Street

Phone Main 6368 


\title{
Appendix B
}

[Text of promotional brochure from the Progressive Educational Association]

\section{Progressive Educational Association}

\author{
gggggggggg \\ The Greatest Proposition Ever Offered for the \\ Benefit of the Race. Absolutely Bona Fide \\ The Future of a Struggling People.
}

\section{THE GREAT OPPORTUNTY}

ggggggggg

Progressive Educational Association, Rev. J. D. Gordon, president, has negotiated for 107,000 acres of the best farming land in the West. Said land is located in the State of Arizona, and is known as Santa Rosa Valley. This fine farming land is set apart for an industrial colony. A town site will be located in the center of the tract, and a college erected for the training of the youth of the Race, for the varied pursuits of life.

\section{OPPORTUNITY FOR THE NEGRO IN THE WEST}

In the State of Mississippi and Oklahoma, where the Negro is oppressed and disfranchised of his God-given privileges and citizen rights, they have seized the opportunity to building for themselves and have made good.

Why not the Negroes in the West, with the knowledge offered them, come together and make a show?

Our people are making a gross mistake in flocking to the great cities of the West, where Organized Labor has the door closed against them, and their wives and daughters have to go out in service and work to pay house rent, and part of the time the men are walking the streets without work.

Some of them are trying to buy homes on the installment plan, and contracting four and five thousand dollars indebtedness, and it takes all their spare money just to keep up the interest.

This same person could take $\$ 440$ and purchase them 80 acres of the best farming land in the West, and the first year he is on the land it will pay for itself, and wife and daughters can remain at home.

The widow woman who is out in service can grow fruit and raise enough poultry to make her life happy, without such hard work.

\section{THE CLIMATE}

There is not another location in the United States that has more suitable climate for the colored man. It is never too hot and never too cold - average 1800 feet above sea level, no heavy frosts and no snow. The plains are green the year round, an ideal climate and a healthy country. Plenty of rain for two 


\section{NATIVE AMERICAN LAND RIGHTS, ARIZONA}

crops a year, the rainy seasons coming one in the winter and the other in the summer months, July, August, and September.

\section{PRODUCTION}

The land will produce cotton, and corn, 50 to 75 bushels per acre; wheat, barley, oats, and other small grain, 40 to 60 bushels per acre; potatoes and beans, peas of all varieties, melons of all kinds, and all semi-tropical vegetables.

FRUTTS

Lemons, oranges, grapes, and all kinds of nuts, and any fruit that grows in any semi-tropical climate.

A smooth table land.

\section{THE SURVEY}

The land will be allotted in 40,80 , and 100 -acre tracts, and the cost per acre will be $\$ 5.50$ for the present.

$$
\begin{aligned}
& \text { TERMS } \\
& 40 \text { acres @ } \$ 5.50=\$ 220.00 \\
& 80 \text { acres @ } \$ 5.50=\$ 440.00 \\
& 100 \text { acres @ } \$ 5.50=\$ 550.00
\end{aligned}
$$

These amounts can be paid on the installment plan if desired.

When the European war comes to a close, and it is made possible for the thousands to come to this country, all thinking people are agreed that all or most of our idle territory will be taken up by the homeseekers. Having this in mind, and also seeking to provide for the Western states a school or university for the religious training of our girls and boys, we desired a location. We have searched California for a desirable place, but could not find in the State just what we wanted.

We have succeeded now in laying hands upon more than 100,000 acres of the best land now idle on the North American continent.

1. There is no alkali in this land anywhere

2. There is no adobe soil in this land

3. There are no rocks on this land

4. There is no sand or sand dunes on this land.

5. Nor can you find gullies in this territory.

6. The land is so level that you would never need to level it for irrigation.

7. This is fine soil for cotton raising.

8. Cattle and hog raising

9. You can produce two crops a year without irrigation: one you plant in December, and the other in June.

10. This land without irrigation, will produce 50 to 60 bushels of wheat to the acre, and then the same year, without irrigation, produce 50 bushels of corn per acre.

11. The wind velocity is an important matter to the western farmer, many have to plant trees around the farm to protect the produce from high winds, but here, according to government reports, the velocity of the wind is from four to seven miles per hour. 


\section{ABORIGINAL HISTORY 1995 19:2}

12. This land, every foot of it, is water bearing, and you can get water from 15 to 50 feet, when you are seeking surface water.

13. The water from the artesian depth is so pure that in using the engine for four consecutive years, the boilers did not have to be cleaned out once during this time.

14.This land will produce the finest cotton possible, and when opened should be a rival to Imperial Valley.

15. It is nearly 1800 feet above the sea level, and out of the reach of fogs.

16. This is an orange producing climate and soil, but we can only know from the fact that $\mathbf{4 0}$ miles away oranges and lemons grown in abundance, therefore we safely conclude that lemons and oranges will grow here.

17. This land, from its productivity powers, is easily worth $\$ 150$ per acre. Everything that we have said about this land can be verified.

Now we are putting 20,000 acres of this land on the market at such a figure that it will startle you. We do so because we have plenty land left, and what we sell at this figure will help us sell the rest of the land for what it is worth.

We have 250 certificates, called "Founders Certificates" which members are to keep for the coming generation and memorial.

These Certificates will cost you $\$ 440$ on terms and will entitle you to cast one vote for the Trustees of the School in this Province, and give you 80 acres of this matchless land, thus letting you have the land at the rate of $\$ 5.50$ per acre. This door will not be open always for the ambitious men and women among us.

One-fourth of all the proceeds from the sales of said land will be placed in escrow for the establishment and endowment of this University thus avoiding the necessity of asking anyone for a donation, white or black. We hope that all Negroes who believe in and delight in the Negro's possibility, will enthusiastically join in with this religious, industrial, civil, and educational movement that promises so much for the Race.

We hope to see a great city, surrounded by a great number of prosperous farmers and cattle raisers, and artisans skilled in every department of hand-craft, and turn out from there to the world, the best articles along all lines, bearing the name and stamp of this great University, and nothing can stop the Race from going on to greatness. The Race cannot go to greatness by saying great things alone, but by our deeds shall we be promoted in this world.

Some of the agents already installed are:

H.H. WILLIAMS, 1315 E. 12th St.

REV. W. H. ROZIER, 5401 Holmes Ave.

MRS. C. A. BASS, 814 Central Ave.

L. C. ROSS, Victorville, Calif.

See these for further information 